\title{
A Comparative Analysis of Contemporary Public Management Concepts in Thailand
}

\author{
Chaiyanant Panyasiri \\ Assistant Professor of Public Administration \\ Siam University, Thailand
}

Received: Sep. 27, 2018 Accepted: Nov. 4, 2018 Online published: Nov. 18, 2018

doi:10.5296/jpag.v8i4.13708 URL: https://doi.org/10.5296/jpag.v8i4.13708

\begin{abstract}
The main purpose of this article is to explore the competing concepts and perspectives in modern Public Management literatures including: New Public Management (NPM), New Public Governance (NPG) and New Public Service (NPS) and to compare the viability of these concepts toward public sectors of Thailand. The method of study relies mostly on documentary research on influential academic writings from well-known Public Administration theorists. This article explores these modern PA concepts in terms of rationale, assumptions, discursive aspects, evolution and development, strengths and limitations, applicability and so on.

The result of the study shows dimensional comparison between various contemporary public management perspectives, including NPM, NPG and NPS in their theoretical backgrounds, perspectives and solutions on public governance in Thailand. Based on the results of the study, to properly adopt these competing modern Public Management concepts, Thailand should pursue a "hybrid" style of public management consisting of all elements from those three modern PA perspectives namely, NPM, NPG and NPS, plus Thai national value of moral and professionalism. The key to the sustainability of Thailand is to retain traditional value that is proven to be relevant and supportive of the responsive and participating form of public governance and to keep up with the postmodernist characteristics of the $21^{\text {st }}$ century.
\end{abstract}

Keywords: old public administration (OPA), new public management (NPM), new public governance (NPG) and new public service (NPS)

\section{Introduction}

Public governance in developing countries is facing challenges both in the landscape of managing the society and the need to embrace on a range of modern public management models. Based on the preliminary research in contemporary Public Management literature, 
this paper highlights the efforts of developing countries in applying New Public Governance (NPG) and New Public Service (NPS) approaches that recognize citizens' participation at the heart of the reform.

To elaborate on these NPG and NPS arguments, the paper explores the limitations of the problems of plurality and fragmentation associated with the New Public Management (NPM) and a shift in the public policy reforms in developing countries which are affected by the global environment and complex and multi-faceted policy problems. These global phenomena, as facing by the governments of developing nations, yield mostly the hybrid forms of public management. In this paper, the result of the study on contemporary perspectives of modern public administration will be analyzed and presented in the form of a comprehensive table comparing each concept of public management and governance, multi-dimensionally. This paper also suggests a shift from traditional form of government toward a greater emphasis on citizen engagement, people motivations and incentives that drive the public service to its finest.

\section{Research Questions}

Competing perspectives on modern Public Administration literatures can be more constructive if being rearranged into a comprehensible order by method of enquiries and investigations on these three research questions:

1) How Public Administration concepts and theories are lining up these days? What comes first and what comes later in modern PA academic literature? How they challenge each other, theoretically and practically?

2) How contemporary Public Management concepts, (including NPM, NPG and NPS), would contribute to the improvement of public management and governance in Thailand?

3) What concept(s) of Public Administration is/are most fit to the context of Developing countries, according to this preliminary research?

In search of all the above mentioned questions, this paper will propose, substantially, solutions that are based on the preliminary review in Public Administration literatures. Developing Countries should maintain a competitive balance as both NPM practitioners and post NPM concepts and construct their own contingency form of government and governance that best fit to their national and global contexts.

\section{Theoretical Review: Competing Paradigms and Concepts of Modern Public Administration}

Modern Public Administration perspectives are known to evolve from Old Public Administration (OPA) toward New Public Management (NPM) and Post NPM concepts that involve competing perspectives of participatory governance including "New Public Governance" (NPG) and "New Public Service"(NPS) During the past three decades, NPM principle has placed state and people relationship basically on Economics and Managerialism principles. For the past three decades in Thailand, NPM principle and practice has caused the 
Thai government to establish many new forms of Thai public agency, apart from its traditional government organization and commercial based public enterprises.

Nevertheless, the global trend in management and the changing socio-political context has led Thai government to consider other competing perspectives of post-NPM era including the "New Public Governance" (NPG) and the "New Public Service" (NPS). These alternatives to NPM concepts introduce to Thai public sector of the new discourse regarding public collaboration of the people (as being perceived as "citizens" not "customers") and redefined Thai government of its new role as a mediator and facilitator of public agendas representing all the sectors of the society.

Regarding the competing paradigms and concepts of modern Public Administration, their theoretical foundations and basic assumptions are summarized and compared in the table 1 below:

Table 1. Comparing theoretical foundations and assumptions of OPA, NPM, NPG and NPS

\begin{tabular}{|c|c|c|c|c|}
\hline $\begin{array}{l}\text { Dimensions / } \\
\text { Perspectives }\end{array}$ & $\begin{array}{l}\text { Old Public } \\
\text { Administration } \\
\text { (OPA) }\end{array}$ & $\begin{array}{l}\text { New Public } \\
\text { Administration } \\
\text { (NPM) }\end{array}$ & $\begin{array}{l}\text { New Public } \\
\text { Governance } \\
\text { (NPG) }\end{array}$ & $\begin{array}{l}\text { New Public } \\
\text { Service } \\
\text { (NPS) }\end{array}$ \\
\hline $\begin{array}{l}1 \text { Theoretical } \\
\text { roots }\end{array}$ & $\begin{array}{l}\text { Political } \\
\text { Science and } \\
\text { Public Policy }\end{array}$ & $\begin{array}{l}\text { Rational/ Public } \\
\text { Choice } \\
\text { Theory/Managerialism }\end{array}$ & $\begin{array}{l}\text { Institutional and } \\
\text { Network Theories }\end{array}$ & $\begin{array}{l}\text { Civic } \\
\text { Participation } \\
\text { and } \\
\text { Democracy } \\
\text { Theory }\end{array}$ \\
\hline $\begin{array}{l}2 \text { Nature of } \\
\text { the state }\end{array}$ & Unitary & Regulatory & Plural and Pluralist & $\begin{array}{l}\text { Plural and } \\
\text { Pluralist }\end{array}$ \\
\hline $\begin{array}{l}3 \quad \text { Assumed } \\
\text { organizational } \\
\text { structure }\end{array}$ & $\begin{array}{l}\text { Bureaucratic } \\
\text { organizations } \\
\text { with top-down } \\
\text { authority and } \\
\text { control of } \\
\text { clients }\end{array}$ & $\begin{array}{l}\text { Decentralized public } \\
\text { organizations with } \\
\text { primary control within } \\
\text { agency }\end{array}$ & $\begin{array}{l}\text { Centralize in } \\
\text { organization but } \\
\text { collaborative } \\
\text { horizontally in } \\
\text { inter-organizational } \\
\text { level relations }\end{array}$ & $\begin{array}{l}\text { Collaborative } \\
\text { structures } \\
\text { with shared } \\
\text { leadership }\end{array}$ \\
\hline $\begin{array}{l}4 \quad \text { System } \\
\text { focus }\end{array}$ & Political system & $\begin{array}{l}\text { Organization } \\
\text { Management }\end{array}$ & $\begin{array}{l}\text { Organization and } \\
\text { its environment }\end{array}$ & $\begin{array}{l}\text { Government } \\
\text { Community } \\
\text { Civil Society }\end{array}$ \\
\hline $\begin{array}{l}5 \text { Nature of } \\
\text { the system }\end{array}$ & Closed & Open -rational & $\begin{array}{l}\text { Both Closed and } \\
\text { Open }\end{array}$ & Open-Natural \\
\hline 6 Value base & $\begin{array}{l}\text { Public sector } \\
\text { ethos }\end{array}$ & $\begin{array}{l}\text { Efficacy } \\
\text { competition } \\
\text { marketplace }\end{array}$ & $\begin{array}{l}\text { Disperse } \\
\text { contested }\end{array}$ & $\begin{array}{l}\text { Disperse and } \\
\text { networking }\end{array}$ \\
\hline $\begin{array}{l}7 \\
\text { Catchphrases }\end{array}$ & $\begin{array}{l}\text { "Bureaucracy" } \\
\text { "Hierarchy" } \\
\text { "Constituent" }\end{array}$ & $\begin{array}{l}\text { "Market Mechanism" } \\
\text { "Customer" } \\
\text { "Contest" }\end{array}$ & $\begin{array}{l}\text { "Citizen" } \\
\text { "Governance" } \\
\text { "Responsive } \\
\text { Governance" }\end{array}$ & $\begin{array}{l}\text { "Shared } \\
\text { Public } \\
\text { Interests" } \\
\text { "Citizen } \\
\text { Engagement" }\end{array}$ \\
\hline
\end{tabular}

Sources: Osborne and Gaebler (1992) Osborne (2010) / Denhardts (2007)/ UNDP (2015)/ Panyasiri (2016) , (2017)

Table 1 illustrates the evolution of Public Administration paradigms from the time of traditional (or old) Public Administration passing through the time of New Public Management to the present time of New Public Governance and New Public Service. The 
table compares contemporary Public Administration thoughts and practices in various dimensions such as the change from Political Science and being an exclusive domain of the government to the free market mechanism and, finally, to civic participation, pluralist society, shared leadership and public interest, all resemble a democratic way of governance.

\section{Contemporary Public Administration in Thailand}

\subsection{Literature Review on New Public Management (NPM)}

Osborne (2010) outlines the key elements of New Public Management (NPM) as: 1) The acceptance and application of business managerial techniques as a path to increase efficiency and effectiveness in public service delivery 2) A focus upon entrepreneurial leadership within public service organizations. 3) An emphasis on inputs and outputs control and evaluation and upon performance management and audit 4) A growth in the use of markets, competition and contracts for resource allocation and public service delivery (Osborne, 2010, p. 3).

Jonathan Boston identifies several characteristics resemble Public Management concepts including: the principle of the universality of management, result based accountability, managerialism before policy making, devolution of centralized power, privatization, outsourcing, competitive tendering, performance agreement, performance based-pay, strategic planning and execution, public perception and image building and monetary incentive (Boston, 1991). All of these elements of NPM enlarge the variety of options for both the government and people to choose, all pertaining to the notion of "Public Choice" (Ostrom and Ostrom, 1971).

Although NPM has been dominated the field of Public Administration for the last three decades, it has been questioned by a wide range of academic and practical grounds, pointing to various of its drawbacks as follows:

1) NPM is not one phenomenon or paradigm, but a cluster of several personae, dependent upon the audience, including ideological, managerial, and research oriented personae. (Ferlie et al. , 1996).

2) The geographic extents of the NPM are limited to the Anglo-American, Australasian and Scandinavian areas, while OPA (Old Public Administration) continues to remain dominant elsewhere. (Hood 1991, Kickert,1997).

3) The nature of NPM itself also geographically variegated. Even upon its originality in the West, are all different from each other both in their focus and locus (Borin, 2002).

Table 2 below is a summary of the knowledge regarding how NPM in developed countries were initiated and practiced. It also addressed their theoretical foundations, the principles and disciplines they are based on, technical practices they employed and the achievement they have made so far, with comparison to the case of Thailand. 
Table 2. New Public Management (NPM) in Public Administration of Developed Countries and Thailand

\begin{tabular}{|c|c|c|c|c|c|}
\hline & New Zealand & Australia & UK & USA & Thailand \\
\hline Initiative & $\begin{array}{l}\text { Trade deficits, } \\
\text { public debts, } \\
\text { inflation }\end{array}$ & $\begin{array}{l}\text { Unemployment } \\
\text { welfare state } \\
\text { Globalization }\end{array}$ & $\begin{array}{l}\text { Efficiency, } \\
\text { Problem of } \\
\text { welfare state }\end{array}$ & $\begin{array}{l}\text { Government } \\
\text { restructuring and } \\
\text { reinventing }\end{array}$ & $\begin{array}{l}\text { Knowledge } \\
\text { diffusion and } \\
\text { political party } \\
\text { policy }\end{array}$ \\
\hline $\begin{array}{l}\text { Theoretical } \\
\text { Foundation }\end{array}$ & $\begin{array}{l}\text { Neo-classic } \\
\text { Economics }\end{array}$ & $\begin{array}{l}\text { Neo-classic } \\
\text { Economics, } \\
\text { Public Choice } \\
\text { Theory }\end{array}$ & $\begin{array}{l}\text { Transaction } \\
\text { cost } \\
\text { Economics }\end{array}$ & $\begin{array}{l}\text { New Managerialism } \\
\text { Open system }\end{array}$ & $\begin{array}{l}\text { Neo-Liberalism, } \\
\text { Thai value } \\
\text { Good } \\
\text { Governance }\end{array}$ \\
\hline $\begin{array}{l}\text { Techniques } \\
\text { and tools }\end{array}$ & $\begin{array}{l}\text { Privatization, } \\
\text { Corporatization }\end{array}$ & $\begin{array}{l}\text { Efficiency } \\
\text { Scrutiny Units }\end{array}$ & $\begin{array}{l}\text { Performance } \\
\text { contracting }\end{array}$ & $\begin{array}{l}\text { National } \\
\text { Performance } \\
\text { Review (NPR) }\end{array}$ & $\begin{array}{l}\text { Various national } \\
\text { strategic plans } \\
\text { and acts }\end{array}$ \\
\hline Competency & $\begin{array}{l}\text { Among the first } \\
\text { successful cases }\end{array}$ & $\begin{array}{l}\text { Achievement } \\
\text { through } \\
\text { flexibility }\end{array}$ & $\begin{array}{l}\text { Market } \\
\text { incentive, } \\
\text { downsizing } \\
\text { accountability }\end{array}$ & $\begin{array}{l}\text { Reinventing } \\
\text { Performance based } \\
\text { Organization_-PBO }\end{array}$ & $\begin{array}{l}\text { Public } \\
\text { Organization } \\
\text { Public officer's } \\
\text { value }\end{array}$ \\
\hline $\begin{array}{l}\text { Shift toward } \\
\text { post-NPM }\end{array}$ & $\begin{array}{l}\text { Participatory } \\
\text { Governance }\end{array}$ & $\begin{array}{l}\text { Participatory } \\
\text { Governance }\end{array}$ & $\begin{array}{l}\text { Community } \\
\text { Governance } \\
\text { New Public } \\
\text { Service }\end{array}$ & $\begin{array}{l}\text { Networking } \\
\text { New Pubic } \\
\text { Governance }\end{array}$ & $\begin{array}{l}\text { Citizenship } \\
\text { Civil Society }\end{array}$ \\
\hline
\end{tabular}

Sources: Hood (1991) / Gore (1991) /Osborne and Gaebler (1992) /Barzeley (2002) /Denhardts (2010)

Comparing the characteristics of New Public Management in Thailand and the West, there are different in several aspects of NPM reinterpretation and practice. In the West, the real initiative is to restructure and to reinvent their public sector for ultimate performance, efficiency and stay innovative. However, in Thailand, NPM were conceived by diffusion of knowledge from Western countries, however, it has been modified to fit with the local value and the context of the country.

Above all, NPM has been challenged for its intra-organizational focus in an increasingly plural world and for its adherence to its inapplicability of the outdated private-sector techniques to public management. According to Osborne (2010), this is the main reason for NPM to be considered outdated and replaceable by other post NPM concepts and techniques. (Osborne 2010).

\subsection{New Public Management (NPM) in Thailand}

For the past two decades (1994-2014), NPM was more than well received in public sector management sphere in Thailand. Academically, NPM dominated Thai Public Administration literatures directing several government reform efforts. Nevertheless, Thai bureaucracy has gradually relinquished NPM and started adopting post New Public Government (NPG) 
concepts emphasizing citizenship, civil participation and collaborative and networking efforts between all sectors in a country. The rationale for embracing more governance practices in the Thai government sector is partly due to various perceptions of NPM limitations as such:

i. The perception of unfitting pattern between NPM principle and the political contexts in developing nations, in which, most of the time, resulted in various interpretations and wishful thinking pedagogy of NPM (as the circle of government, academician, technocrat and practitioner in the developing countries want people to believe and act according to their proposed interpretation of NPM ).

ii. Many developing nations still lack of basic infrastructure required to uphold the system that supposed to serve people as being "a customer", be it knowledge in modern management, economic perspective on resource allocation, the sincerity of the government to acknowledge their people as customers as well as lacking of resources and facilities to serve public "NPM" wisely, and so on. (Robinson, 2015, p. 9)

iii. The entrepreneurial spirit imbued in the public sector as advocated by NPM is not realistic enough for initiating changes and entrepreneurial spirit and mind among the public officers, executive and policy makers in developing countries.

iv. As long as the system of check and balance and public accountability are not fully developed, it is unlikely for the developing countries to follow NPM to its course. Indeed, NPM practice of deregulation and flexibility in the process of law and regulations was being blamed for causing the acts of policy frauds and all sorts of corruption easily ridden into the government system.

v. Comparing to business area, the complexity of public administration and policy management has far greater impact on individual life. NPM principle of business style public management is not much of an answer to public demand of fair and responsive public service. Moreover, there is an increased shared public perception that business style of government as advocated by NPM was causing more social inequalities (Panyasiri, 2017, p. 15).

\subsection{Literature Review on New Public Governance (NPG)}

New Public Governance (NPG) refers to: a new process of governing; or a changed condition of ordered rule; or the new method by which society is governed. Rhodes applied the idea to public administration and public policy to refer the changing boundaries between public, private and voluntary sectors. According to Rhodes, "governance" refers to governing with and through networks; the network steering. A shift from 'government to governance' requires the mix of bureaucracy, markets and networks to mobilized public policy and public sector. (Rhodes, 1996: 652) 
According to Rhodes (1997), the term "governance" is popular but imprecise. It has at least six uses referring to: the minimal stage: corporate governance: the new public management: 'good governance': socio-cybernetic systems: and well-organizing network. Rhodes stipulates that governance refers to "self-organizing inter-organization networks" and argue that this network complement markets and hierarchies as governing structure for authoritatively allocating resources and exercising control and co-ordination

Nevertheless, NPG has become one among the dominant contemporary concepts on public sector management with a number of terms addressing it (i.e., Responsive Governance, Network Governance, Public Services Governance and Good Governance, etc). In this article, the term "New Public Governance--NPG" refers to "the formal and informal arrangements that determine how public decisions are made and how public actions are carried out". This paper explains NPG as the way in which societal rules, norms and actions are structured, sustained, regulated and held accountable by people participation and the network of collaborations among social entities.

In the area of Policy Studies, this novel idea of Public Administration appears within a number of World Bank reports in the early 1990s. (World Bank 1992; 1994). Accordingly, World Bank highlights the importance of the practice of "governance" as vital to development of a country. World Bank defined the term "governance" as "the manner in which power is exercised in the management of a country's economic and social resources for development" (World Bank, 2003). Notably, the term is not specific to government or the public sector but involves all possible stakeholders in the process of development. Nevertheless, Osborne asserts that NPG is neither a normative new paradigm to supersede OPA and NPM nor a tool to overcome the challenges in the environment of public agencies in these days.

In the article: The (New) Public Governance: a suitable case for treatment? Stephen P. Osborne outlines his three main arguments regarding the modern perspective on Public Administration as follows:

First, although the New Public Management (NPM) concept has redefining the discipline of Public Administration for the last three decade in many ways, challenging a century of the hegemony of traditional Public Administration, it is not be equated as a "paradigm shift". According to Osborne, NPM should be recognized as a transitory stage in the evolution from traditional Public Administration to what he proposed as the "New Public Governance" (NPG) (Osborne, 2010).

Second, Public Administration has passed through three main concepts of policy implementation and public service delivery including the Old Public Administration (OPA) from the late $19^{\text {th }}$ century to the early $1980 \mathrm{~s}$, the NPM through the start of $21^{\text {st }}$ century and the emergent of the participatory forms of public Governance (NPM). Nevertheless, the elements of each concepts may coexist with each other, thus in an overlapping pattern. (i.e. both OPA and NPG contain strong elements of hierarchy) (Osborne, 2010).

Third, both OPA and NPM are virtuous in their own rights, (i.e. OPA has been successful in 
its exploration of the essentially political nature of public policy implementation and public service delivery (Pfiffner, 2004). NPM has been successful in its complexity and precision in the public management system in the search of change and innovation), however, they are no longer recognized as viable concepts in modern Public Administration for their inability to " capture the complex reality of the design, delivery and management of public services in the twenty-first century" (Osborne, 2010).

According to contemporary discourse in Public Administration, the terms "governance" and "public governance" are not the new terms and are existed with considerable theoretical grounds and knowledge. (Rosenau, 2008). Indeed, academicians have differentiated certain aspects of governance discourse prior to NPG including: governance, corporate governance, "good" governance, public governance and "digital governance".

"Governance" can be defined as processes of governing (whether undertaken by government, market or network, whether over a family, tribe, formal or informal organization or territory and whether through the laws, norms, power or language) that involved the condition of interaction and participative decision-making of the people along with state and other stakeholders (Bevir, 2013).

"Corporate Governance" is concerned with the internal systems and processes that provide direction and accountability to the performance and outcomes of any kind of organization according to their missions to the public.

"Good" Governance (or "Good Governance" in the public management discourse in many developing countries) is concerned with the promulgation of normative models of social, political and administrative governance by supranational institutions such as World Bank, UN, OECD and so on. (United Nations, Department of Economic and Social Affairs, 2015).

Digital Governance involves public activities of utilizing the full potential of new digital technologies to change the way to interact between government agencies, business and civic sector and to transform the way the government transacts its activities in public policy process.

Despite many of its affiliated terms, the core substances of the New Public Governance include the ruling systems in which steering mechanism are employed to frame and implement goals that move communities in the directions they wish to go or that enable them to maintain the institutions and policies they wish to maintain (Rosenau, 1995). According to Rosenau, "community" is an active partner in public policy process along with public agencies.

The World Bank (1992) conceptualizes the term "governance" as the exercise of political power to manage a nation's affairs. In achieving the goal of governance under public sector management, three essential components are 1) a legal framework for development, 2) accountability, and 3) transparency and information. The World Bank emphasizes that good governance requires two aspects: legitimacy and capacity. Kickert (1993) and Rhodes (1997) define the term 'governance' as the machinery of "self-organizing inter-organizational networks" that function both with and without government to provide public services. 
In response to a preliminary question of regarding the differences between "government" and "governance", Osborne (2006) noted that "governance" is predicated upon the existence of a plural state and a pluralist state. The latest shift towards network forms of collaboration and horizontal ties between government, business, community and civil society is largely in line with the move toward what Osborne refers to as the "process of governance"(Osborne, 2006). Considering their underlining assumption, "government" and "governance" is not the same thing. While "government" is about administering public authority by state to generate rules and regulations in a society, "governance", on the other hand, focuses on active collaboration between state, people and other sectors in policy process and the delivering of services to people as a community citizen. In a way, governance always incorporated participative and process-oriented elements of governing (Pestoff, 2010).

According to contemporary literature in PA, "to govern" becomes more and more irrelevant within the global management context seeking more participative way to govern. Among those competing paradigms in modern public management, New Public Governance (NPG) has been known to challenge the New Public Management (NPM) for a place of mainstream contemporary perspective of public administration. Under NPG concept, government is expected to be responsive, efficiently and effectively, to people's real needs. The concept of NPG requires a more responsive governance practice that entails public sector's actions on executing policies, strategies, programs, activities and resources by taking into account of people's expectation, with particular emphasis to community and civic participation (Cope, et al., 1997).

\subsection{New Public Governance (NPG) in Thailand}

Thailand has faced complexity of problems stemming from its long term "middle income trap", hindering its path to graduate from labor intensive industry nation to knowledge-based and innovation oriented nation. Facing such long-term challenge, the Thai public management spheres are working toward a more responsive and collaborative way of governance by engaging business sectors and civic sectors in policy process. Public governance of multi-stakeholder partnerships will provide Thailand a forum for creativity, social entrepreneurship and world class producer of ideas and innovation, all conditions enabling the planned mobility of Thailand toward an advanced economy status.(Thailand Board of Investment, 2017). The concept of NPG, when deeply understood and commonly practiced among all three essential parts of the nation (including state, people and business), will enhance trust between government and its people (Patthranarakul and Panyasiri, 2017).

\subsection{Literature Review on New Public Service (NPS)}

According to UNDP Global Centre for Public Service Excellent (2015), New Pubic Governance (NPG) concept introduces the idea of plural and pluralist state in which government is no longer the sole force shaping public policy. Among many of NPG elements, New Public Service (NPS) is known to be technical continuities of the conceptual and theoretical aspects of NPG.(GCPSE, 2005: 2). In Janet Denhardt and Robert Denhardt (2003), "The New Public Service", the authors offer a synthesis of the ideas that are opposed to the New Public Management (NPM). The Denhardts present their seven principles of NPS: 
1. Serve citizens, not customers: the public interest is the result of the dialogue about shared values rather than the aggregation of individual interest (as mentioned in NPM concept)

2. Seek the public interests: It is not suitable for public manage to seek just a quick solution driven by individual preference.

3. Value citizenship over entrepreneurship: just as it is "citizenship before entrepreneurship", public manager act with the consult of citizen not act like a business manager who investing public money rather at their own view.

4. Think strategically, act democratically (In comparison to Osborne and Gaebler, Denhardt and Denhardt assert that there is a difference between thinking strategically and entrepreneurial government.)

5. Recognize that accountability is not simple: Public manager should be attentive to more than the market (i.e. law, community value, political norms, professional standards and citizen interests).

6. Serve rather than steer: it is increasing important for public manager to use shared, value based leadership in helping citizens articulate their shared interest rather than steering society to their designate direction.

7. Value people, not just productivity: Operate through processes of collaboration and shared leadership based on respect for all people

According to NPS, the role of the public administrator is much more complex and cannot simply act as a manager in the business sense by performing cost-benefit analysis. As Denhardt and Denhardt explain, in the NPS perspective, the public administrator is not the lone arbitrator of the public interest. Rather, the public administrator is seen as a key actor within a larger system of governance including citizens, groups, elected representatives, as well as other institutions.

The New Public Service (NPS) concept starts with the premise that modern public management should be centered on citizen, community and civil society. According to Denhardt and Denhardt, NPS build upon the principle of democracy in which the primary role of the government is to help citizens articulate their demand in policy process. NPS theorists reject both the premise of NPM that focuses on the interaction of public managers and individual with a self-interest as a buyer and Old Public Administration perspective of people as clients and constituents that passively await top down public service delivery from the Bureaucracy. Being a democratic theory based, NPS is, therefore, more of a belief in the plurality and engagement than both top-down or market oriented public policy management and service delivery (Perry, 2007).

NPS concept encompassing these ways of thoughts and practices in public affairs including: 1) modern public management from the vantage point of Democratic principle in which government need to be opened, accountable, accessible and responsive in serving citizens. 2) People 's role as citizens who look beyond their self-interest to the wider public interest. 3) 


\section{Macrothink Institute ${ }^{\text {TM }}$}

The role of public government in facilitating citizen engagement to resolve complex public issues resulted from today globalized environment and 4) The importance of a public service ethos, emphasizing the value, commitment and motivations of public officers dedicated to public interest of a wider scale (Denhardt and Denhardt, 2000).

Similarly, Bourgon (2007) includes the concepts of democratic citizenship into the new perspective on Public Management under these four principles: 1) Building collaborative relationships with citizens and group of citizens. 2) Encouraging shared responsibility among citizens and across all public management institution 3) Disseminating information to elevate public discourse and to foster a shared understanding of public issues and 4) Constantly and consistently involve and engage citizens in government and public policy issues and activities. (Bourgon, 2007).

A table below explains the managerial aspects offered by these competing paradigms of Public Administration as follow As the review of literature on modern Public Administration paradigms and concept has been covered so far including Old Public Administration, New Public Management, New Public Governance and New Public:

Table 3. Comparing managerial perspectives: OPA, NPM, NPG and NPS

\begin{tabular}{|c|c|c|c|c|}
\hline $\begin{array}{l}\text { Dimensions / } \\
\text { Key elements }\end{array}$ & $\begin{array}{l}\text { Old Public Administration } \\
\text { (OPA) }\end{array}$ & $\begin{array}{l}\text { New Public } \\
\text { Administration (NPM) }\end{array}$ & $\begin{array}{l}\text { New Public } \\
\text { Governance } \\
\text { (NPG) }\end{array}$ & $\begin{array}{l}\text { New Public } \\
\text { Service } \\
\text { (NPS) }\end{array}$ \\
\hline $\begin{array}{l}1 \text { Public } \\
\text { Service } \\
\text { problems }\end{array}$ & Order and efficiency & $\begin{array}{l}\text { Performance and } \\
\text { efficiency }\end{array}$ & $\begin{array}{l}\text { Integrity and } \\
\text { Responsiveness }\end{array}$ & $\begin{array}{l}\text { Participation } \\
\text { and engagement }\end{array}$ \\
\hline $\begin{array}{l}2 \text { Conception } \\
\text { of the public } \\
\text { interest }\end{array}$ & Political, enshrined in law & $\begin{array}{l}\text { Aggregation of } \\
\text { individual interests }\end{array}$ & $\begin{array}{l}\text { Collaborative } \\
\text { pubic agendas } \\
\text { between state, } \\
\text { people and } \\
\text { other institution }\end{array}$ & $\begin{array}{l}\text { Dialogue about } \\
\text { shared values }\end{array}$ \\
\hline $\begin{array}{l}3 \text { To whom are } \\
\text { public officer } \\
\text { responsive? }\end{array}$ & Clients and constituents & Customers & Citizens & Citizens \\
\hline $\begin{array}{l}4 \text { Roles of } \\
\text { government }\end{array}$ & $\begin{array}{l}\text { "Rowing", implementation } \\
\text { focused on politically } \\
\text { defined objectives }\end{array}$ & $\begin{array}{l}\text { "Steering" serving as } \\
\text { catalyst to unleash } \\
\text { market force }\end{array}$ & $\begin{array}{l}\text { "Facilitating" } \\
\text { help } \\
\text { people/citizens } \\
\text { articulate their } \\
\text { needs and } \\
\text { aggregated into } \\
\text { real public } \\
\text { agenda } \\
\text { represent public } \\
\text { real interests }\end{array}$ & $\begin{array}{l}\text { "Serving", } \\
\text { negotiating and } \\
\text { brokering } \\
\text { interests among } \\
\text { citizens }\end{array}$ \\
\hline 5 Mechanisms & Administering & mechanisms & Focusing & Building \\
\hline
\end{tabular}




\begin{tabular}{|c|c|c|c|c|}
\hline $\begin{array}{l}\text { for achieving } \\
\text { policy } \\
\text { objectives }\end{array}$ & government & $\begin{array}{l}\text { and incentive through } \\
\text { private and non-profit } \\
\text { agencies }\end{array}$ & $\begin{array}{l}\text { governance } \\
\text { model } \\
\text { involving } \\
\text { citizen, } \\
\text { community and } \\
\text { civil society }\end{array}$ & $\begin{array}{l}\text { coalitions of } \\
\text { public, business } \\
\text { and non-profit } \\
\text { agencies }\end{array}$ \\
\hline $\begin{array}{l}6 \text { Approach to } \\
\text { accountability }\end{array}$ & $\begin{array}{l}\text { Hierarchical-administrators } \\
\text { responsible to elected } \\
\text { leaders }\end{array}$ & $\begin{array}{l}\text { Market-drive-outcomes } \\
\text { result from } \\
\text { accumulation } \\
\text { self-interests }\end{array}$ & $\begin{array}{l}\text { Accountability } \\
\text { assured through } \\
\text { civic sector, } \\
\text { information } \\
\text { disclosure and } \\
\text { dispersion and } \\
\text { citizen } \\
\text { engagement }\end{array}$ & $\begin{array}{l}\text { Professionalism } \\
\text { guided by law, } \\
\text { values, norms } \\
\text { and citizen } \\
\text { interests }\end{array}$ \\
\hline $\begin{array}{l}7 \\
\text { Administrative } \\
\text { discretion }\end{array}$ & $\begin{array}{l}\text { Limited discretion granted } \\
\text { to public officials }\end{array}$ & $\begin{array}{l}\text { Wide latitude to meet } \\
\text { entrepreneurial goals }\end{array}$ & $\begin{array}{l}\text { Increased } \\
\text { central } \\
\text { monitoring but } \\
\text { more emphasize } \\
\text { on horizontal } \\
\text { collaboration }\end{array}$ & $\begin{array}{l}\text { Discretion } \\
\text { granted but } \\
\text { constrained and } \\
\text { accountable }\end{array}$ \\
\hline 8 Emphasis & $\begin{array}{l}\text { Policy creation and } \\
\text { implementation }\end{array}$ & $\begin{array}{l}\text { Management of } \\
\text { organizational resource } \\
\text { and performance }\end{array}$ & $\begin{array}{l}\text { Aggregation } \\
\text { and negotiation } \\
\text { of value, } \\
\text { meaning and } \\
\text { relationships }\end{array}$ & $\begin{array}{l}\text { Citizen, } \\
\text { community, } \\
\text { civil society and } \\
\text { democracy }\end{array}$ \\
\hline $\begin{array}{l}\text { 9Resource } \\
\text { allocation } \\
\text { mechanism }\end{array}$ & Hierarchy & $\begin{array}{l}\text { Market mechanism and } \\
\text { contract }\end{array}$ & $\begin{array}{l}\text { Negotiation of } \\
\text { meaning and } \\
\text { relationships }\end{array}$ & $\begin{array}{l}\text { Civic } \\
\text { participation, } \\
\text { negotiation and } \\
\text { dialogue }\end{array}$ \\
\hline $\begin{array}{l}10 \text { Future } \\
\text { Prospect in } \\
\text { Thai Public } \\
\text { Management } \\
\text { sphere }\end{array}$ & $\begin{array}{l}\text { Best fit with political value } \\
\text { and culture inherent in the } \\
\text { nation. }\end{array}$ & $\begin{array}{l}\text { Blamed for moral hazard } \\
\text { and make people only } \\
\text { care for themselves (as } \\
\text { customers) However, } \\
\text { public officers still } \\
\text { reluctant to abandon it. }\end{array}$ & $\begin{array}{l}\text { Useful for } \\
\text { determining the } \\
\text { new direction } \\
\text { reference and } \\
\text { foundation of } \\
\text { national agenda } \\
\text { on reforming the } \\
\text { country. }\end{array}$ & $\begin{array}{l}\text { Grand Narrative } \\
\text { and hegemonic } \\
\text { discourse on } \\
\text { Thailand holistic } \\
\text { reform but no } \\
\text { democratic } \\
\text { origin to refer to. }\end{array}$ \\
\hline
\end{tabular}

Sources: Sources: Osborne and Gaebler (1992) / Osborne (2010) / Denhardts (2007)/ UNDP (2015)/ Panyasiri (2016) , (2017)

The table provides answers to the question of "to whom the public agencies (in each 
paradigm) are accountable for?" Public agencies are expected to be accountable to clients and constituents, to customers and finally, to the citizen of the nation. In addition, by comparing these PA paradigms, the expected role of government has been evolved from "rowing" (OPA) to "steering" (NPM) and, finally, "serving", in the post-NPM era of Public Governance.

\subsection{New Public Service (NPS) in Thailand}

After the 2014 coup, the National Council for Peace and Order (NCPO) and the interim government of Thailand pushed their efforts for solving conflicts and improving long-term stability. National strategies and new public governance models are initiated as engines of growth for achieving long-term development goals. As Thailand is in a transitional stage and faces with new challenges from rapid change and globalization, its future challenges are to cope with dynamic changes from internal and external factors with its self-developed national capacity (Pathranarakul and Panyasiri, 2017).

By implementing a new governance model called "Pracharat" (civil state) in line with NPG and NPS concepts, Thai government aim to create synergy among key political stakeholders for national reconciliation and further progress. This shift to public sector governance is considered one key component for ensuring the country long-term sustainability.

For the last two decades, Public Administration in Thailand is conducted along NPM guideline. However, since the year 2014, Thai national agendas were shift to the concepts and ideas of public governance as the interim military government reassert the importance of "citizenship" in which Thai people are no longer entitle to be perceived as "clients" or "constituents" (as in old PA paradigm) or "customers / "service users" (as in NPM perspective). Supportive by the discourse of "Pracharat" (civil state), Thai people are now the "citizens" (of the nation) that live their life for an overall public interests of the country and required to be faithfully perform their civic duty.

Considering political and societal contexts and situations in Thailand, NPS seems to gain advantage over NPM as Public administration models responsive to internal and external challenge of the country. At Least, for this time being, NPS concepts gain their places in the modern time public management discourse in Thailand that favors the usage of special authority in running the country. In addition, the shared public value inherent in cultural background that bias toward totalitarian way of governance is highly tolerated in Thai politics and public administration. Consequently, the assumptions and values lies within NPM principle that honors the reasonability of personal judgment might not be fully welcomed in some developing countries where irrationalities and lack of transparency always rules public scenes and perceptions. Therefore, in the case of Thailand, civic participation and networks of governance in line of NPG and NPS concepts gradually replacing NPM (that rely on business like method on public management) as the main stream of Public Administration (Panyasiri, 2017).

\section{Conclusion}

The academic and practical virtues of NPM and Post NPM (i.e. NPG/ NPS/ Postmodern 
Management and Thai value of good governance (in the case of Thailand)), are all relative to their context of usage. For example, the New Public Management concept (NPM) is a universal management principle compatible and adaptable to various types of organizational mission including the old pattern of bureaucratic agency that in-charge of government and security affairs, public enterprise that provide infrastructure and basic of living resources to people and various new patterns of modern public organizations that facilitate the competency of Thailand in global competitive environment and sustainability of the nation in the long run. For those new forms of public organization, NPM knowledge and techniques are driven mechanisms to their success and expansion of their kind in Thai public policy sphere.

For NPG and NPS concept, "public accountability" is more important than responding to the demand of people as consumer. Comparing to NPM perspective in which market mechanism redefines people and state relationship, these post NPM concepts are more responsive to people participation, civic engagement and democratic principle, all underlining the status of citizenship of the nation. As being citizens, people are expected to be committed to rights, duty and responsibility while the government and its officers should focus on the "serving" part. NPG and NPS represent a great leap from "government" paradigm that rely on power and authority of the state to a "governance" paradigm in which civic engagement that allow people to set their own course of self-determination, shared value and collaborating their ways to the ultimate goal for the whole society (not aggregate individual goals as NPM advocates) By comparing to NPM, NPG and NPS are more focused on public accountability than fulfilling personal and individual interests under free market mechanism.

Consequently, under the post NPM perspectives, government and its officer must "serve" the citizen by refrain from using top down authority or any kind of market mechanism to carry out its policy agendas but to facilitate, instilling, coordination and connecting those shared value among citizen, community, civic sectors and all part of the governance system of the countries. NPG and NPS see the way to efficiency and effectiveness of public governance of a nation will only be secured through strong collaborative networks between government and its active citizen. This scenario will create the system of check and balance, monitoring for transparency and accountability between and among the public, private and civic sectors, all hardly be achieved through the free market and neo-classic economics path advocated by NPM. When the world approached a new millennium, Public participation or civic participation as a part of democratic way of governance, began to overtaken NPM in Public Administration literature and practice, now developing countries, then Western countries.

Comparing to other Public Management perspectives (including those representing the post NPM perspectives), NPM theorists seem to be much more explicit on the relationship between government administration and its citizens. This is because they use the customer service model from applied from business management. The administrative role is further streamlined by moving as many choices as possible out of the political arena by converting those policy alternatives into market choices. Although NPG and NPS theorists assign responsibility to the public administrator, and at the same time stress the importance of public participation and community decision-making, their exact allocation of responsibility and power among these 
stakeholders is still unclear and remains quite abstractive in operationalization and in measuring of the outputs and outcomes.

Due to the methodological and technical limitations inherent in each modern PA perspective, it is legitimate for a country to be selective in adopting these ideas. In the case of Thailand, both NPM visibility and domination of Thai public management will continue as well as NPG/NPS adaptability and learning prospect are on their ways to transform Thai political and administrative sphere suitable for its context and ultimate goal ; sustainability It is more useful for us to look at the macro level of public management and no need to choose any concepts over the others and be selective and adapt to any of these public management ideas and concepts since the result of our development goal is to be achieved by efficient mechanism of the state in supporting people to entitled to better quality of life and sustainability of the whole society. Consequently, a "hybrid" style of public management drawing elements of all three modern PA perspectives namely, NPM, NPG and NPS, plus national value of moral and professionalism, is the right direction should the developing nation proceed in order to survive and prosperous in the $21^{\text {st }}$ century global management context.

\section{References}

Barzeley, M. (2002). Origin of the New Public Management: An International View from Public Administration / Political Science. In McLaughin, K. Osborne , S. and Ferlie, E. (eds.), New Public Management: Current Trends and Future Prospects. London: Routledge.

Bevir, M. (2013). Governance: A Very Short Introduction. Oxford: Oxford University Press.

Borin, S. (2005). New Public Management, North American Style. In McLaughlin, K., Osborne, S., \& Ferlie, E. (eds.). The New Public Management: Current Trends and Future Prospect. London: Routledge

Boston, J. (1991). The Theoretical Underpinning of Public Restructuring in New Zealand: Reshaping the State. Auckland: Oxford University.

Bourgon, J. (2007). Responsive, Responsible and Respected Government: Toward a New Public Administration Theory. International Review of Administrative Sciences, 73, 7-26. https://doi.org/10.1177/0020852307075686

Cope, S., Leishman, F., \& Strarei, P. (1997). Globalization, New Public Management and the enabling State. International Journal of Public Sector Management, 10(6), 444-460. https://doi.org/10.1108/09513559710190816

Denhardt, J. V., \& Denhardt, R. B. (2007). The New Public Service: Serving, not Steering. New York: M.E. Sharpe.

Denhardt, R. B., \& Denhardt, J. V. (2000). The New Public Service: Serving rather than Steering. Public Administration Review. 60(6) 549-559. https://doi.org/10.1111/0033-3352.00117

Ferlie, E., Ashburner, L., Fitzgerald, L., \& Pettigrew, A. (1996). New Public Management in Action. New York: Oxford University Press. 
https://doi.org/10.1093/acprof:oso/9780198289029.001.0001

Frederickson, G., \& Smith, K. (2003). The Public Administration Primer. Boulder, Colorado: Westview Press.

Global Center for Public Service Excellence, UNDP (2005). "From Old Public Administration to the New Public Service" A Report Summary. Retrieved from www.undp.org/publicservice

Gore, A. (1995). Common Sense Government: Work Better and Less. New York: Random House

Hood, C. (1991). A Public Management for All Seasons? Public Administration, 69(1) 3-19. https://doi.org/10.1111/j.1467-9299.1991.tb00779.x

Kickert, W. (1993). Complexity Governance and Dynamics: Conceptual Explorations of Public Network Management. In J. Kooiman (ed.) Modern Governance, London: Sage

Osborne, S. (2010) The (New) Public Governance: A Suitable Case for Treatment? in Osborne, S. (ed.) The New Public Governance: Emerging Perspectives on the Theory and Practice of Public Governance. London/New York: Routledge. https://doi.org/10.4324/9780203861684

Osborne, S., \& Gaebler, T. (1992). Reinventing Government: How the Entrepreneurial Spirit is Transforming the Public Sector from School House to State House. Reading, Massachusetts: Addison-Wesley.

Osborne, S. (2006). The New Public Governance. Public Management Review. Retrieved from http://www.tandf.vo.uk/journals.

Ostrom, V., \& Ostrom, E. (1971). Public Choice: A Different Approach to the Study of Public Administration. Public Administration Review, 31(2), 203-216. https://doi.org/10.2307/974676

Panyasiri, C. (2016). The Paradigm Shift of Public Administration in Thai Bureaucracy: A Comparative Case Study of Thai Government Agencies and Public Enterprises. Journal of Thonburi University, 10(2), 46-60.

Panyasiri, C. (2017). Management Paradigms of Public Administration: A Comparison between New Public Management (NPM) and New Public Service (NPS). Siam Academic Review, 18(1), 8-26.

Pathranarakul, P., \& Chaiyanant, P. (2017). Public Sector Governance and Transformation in Thailand: A Policy Framework towards Sustainable Development. 2017 EROPA General Assembly and Conference on "The Role of Public Governance in Achieving the Sustainable Development Goals (SDGs): Transforming, Empowering and Network-Building" 11-15 September 2017, Seoul, Republic of Korea

Perry, J. (2007). Democracy and the New Public Service. The American Review of Public Administration. https://doi.org/10.1177/0275074006296091 
Pestoff, V. (2011). Co-production, New Public Governance and Third Sector Social Services in Europe. In Osborne. S. (ed.) The Third Sector in Europe: Prospect and Challenges. London/New York, Routledge

Pfiffner, J. (2004). Traditional Public Administration versus the New Public Management: Accountability versus Efficiency. In Benz, A. Siedentoph, H.and Sommermann, K.P. (eds). Institutionenbildung in Regierung und Verwaltung ; Festschriff fur Klaus Konig. Berlin: Duncker and Humbolt.

Rhodes, R. A. W. (1996). The New Governance: Governing without Government. Political Studies, 44(4), 652-67. https://doi.org/10.1111/j.1467-9248.1996.tb01747.x

Rhodes, R. A. W. (1997). Understanding Governance: Policy networks, Governance, Reflexivity and Accountability. Buckingham, UK: Open University Press.

Robinson, M. (2015). From Old Public Administration to the New Public Service: Implications for Public Sector Reforms in Developing Countries. Singapore: Global Centre for Public Service Excellent, UNDP.

Rosenau, J. N. (1995). Governance in the Twenty-first Century. Global Governance, 1, $13-43$.

Rosenau, J. N. (2008). Governance without Government: Order and Change in World Politics. London: Cambridge University Press.

Thailand Board of Investment (2017). Thailand 4.0 Means Opportunity in Thailand. Thailand Investment Review.

United Nations, Department of Economic and Social Affairs (2015). Responsive and Accountable Public Governance 2015 World Public Sector Report

World Bank (1989). Sub-Saharan Africa: From Crisis to Sustainable Growth. Washington: World Bank.

World Bank (1992). Governance and Development. Washington: The World Bank. https://doi.org/10.1596/0-8213-2094-7

World Bank (1994). Governance: The World Bank's Experience. Washington: The World Bank. https://doi.org/10.1596/0-8213-2804-2

World Bank (2003a). Reforming Public Institutions and Strengthening Governance: A World Bank Strategy Implementation Update. Washington: The World Bank.

\section{Copyright Disclaimer}

Copyright for this article is retained by the author(s), with first publication rights granted to the journal.

This is an open-access article distributed under the terms and conditions of the Creative Commons Attribution license (http://creativecommons.org/licenses/by/4.0/). 